Columbia University Law School

Center for Law \& Economics Studies Research Paper Series

Paper No. 360

and

Yale University Law School

Studies in Law, Econ and Public Policy Research Paper Series

Paper No. 394

\title{
Contract Interpretation Redux
}

\author{
ALAN SCHWARTZ \\ Yale Law School \\ ROBERT E. SCOTT \\ Columbia University - Law School
}




\title{
CONTRACT INTERPRETATION REDUX
}

\author{
Alan Schwartz* and Robert E. Scott**
}

FORTHCOMING 119 YALE L. J. (2010)

Contract interpretation remains the largest single source of contract litigation between business firms. In part this is because contract interpretation issues are difficult, but it also reflects a deep divide between textualist and contextualist theories of interpretation. While a strong majority of U.S. courts continue to follow the traditional, formalist" approach to contract interpretation, some courts and most commentators prefer the "contextualist" interpretive principles as exemplified by the Uniform Commercial Code and the Second Restatement. In 2003, we published an article that set out a formalist theory of contract interpretation to govern agreements between business firms. We argued that, although accurate judicial interpretations are desirable, accurate interpretations are costly for parties and courts to obtain. Thus, any socially desirable interpretive rule would trade accuracy off against contract writing and adjudication cost. This trade-off implies that risk neutral business parties will commonly prefer judicial interpretations to be made on a limited evidentiary base the most important element of which is the contract itself. But importantly, we also argued that commercial parties' preferences along this dimension will be heterogeneous. Thus, any interpretation rules the state adopts should be defaults and the state should defer to the expressed preferences of particular parties regarding interpretation. This Review Essay clarifies and extends these arguments which have prompted a number of anti-formalist responses. We respond to our critics and summarize empirical data that support our theory. Although much academic commentary suggests otherwise, both the available evidence and prevailing judicial practice support the claim that sophisticated parties prefer textualist interpretation. Sophisticated commercial parties incur costs to cast obligations expressly in written and unconditional forms to permit a party to stand on its rights under the written contract, to improve party incentives to invest in the deal, and to reduce litigation costs. Contextualist courts and commentators prefer to withdraw from parties the ability to use these instruments for contract design. The contextualists, however, cannot justify rules that so significantly restrict contractual freedom in the name of contractual freedom.

* Sterling Professor of Law, Yale Law School; Professor, Yale School of Management.

** Alfred McCormack Professor of Law and Director, Center for Contract and Economic Organization, Columbia University. We are grateful to Victor Goldberg, Jody Kraus, Daniel Markovits, Elizabeth Scott and George Triantis for helpful comments. 


\section{INTRODUCTION}

Interpretation issues are hard; the doctrine is difficult and the issues complex. Courts divide over whether to retain the common law's "textualist" rules of interpretation or to apply "contextualist" interpretive principles as exemplified by the Uniform Commercial Code and the Second Restatement. ${ }^{1}$ States holding the former view are led by New York while California is the most significant contextualist jurisdiction. ${ }^{2}$ Perhaps understandably, given the doctrinal complexities and jurisdictional divisions, much of the scholarly commentary is unhelpful. This is unfortunate because contract interpretation remains the largest single source of contract litigation between business firms. ${ }^{3}$

In 2003, we published an article that, among other things, set out a theory of contract interpretation to govern agreements between business firms. ${ }^{4}$ The arguments we advanced were part of a larger project arguing that the law should pursue the first order goal of maximizing contractual surplus when it chooses rules to regulate merchant to merchant contracts. ${ }^{5}$ The article

\footnotetext{
${ }^{1}$ A strong majority of U.S. courts continue to follow the traditional, "formalist" approach to contract interpretation. A state by state survey of recent court decisions shows that 38 states follow the traditional textualist approach to interpretation. Nine states, joined by the Uniform Commercial Code for sales cases (hereinafter UCC) and the Restatement (Second) of Contracts, have adopted a contextualist or "anti-formalist" interpretive regime. The remainder are indeterminate. See state by state survey on file with the Yale Law Journal; and UCC §§2-202, 2-208, 1-205 and Restatement (Second) of Contracts $\S \S 200-04,209-18$.

${ }^{2}$ See infra text accompanying note 15.

${ }^{3}$ Judge Richard Posner has estimated that many if not a majority of the contract cases he sees present interpretation disputes, See e.g., Richard Posner, The Law and Economics of Contract Interpretation, 83 Texas L. Rev. 1582 (2005). An early empirical study found that $26 \%$ of a sample of 500 cases raised interpretation and parol evidence issues, Shepherd, Contracts in a Prosperity Year, 6 Stan. L. Rev. 208, 223 (1954). See also David Dilts, Of Words and Contracts: Arbitration and Lexicology, 60-JUL Disp. Resol. J. 41 (2005) ("The construction of contract language is the controversy most evident in contract disputes.") and John P. Tomaszewski, The Pandora's Box of Cyberspace: State Regulation of Digital Signatures, 33 Gonz. L. Rev. 417 (1997-1998) ("Most contract litigation involves disputes over

${ }^{4}$ Alan Schwartz \& Robert E. Scott, Contract Theory and the Limits of Contract Law, 113 Yale L. J. 541 (2003) (herein "Contract Theory").

${ }^{5}$ As appears below, an intelligent pursuit of this goal satisfies such second order goals as predictability and stability.
} 
has generated substantial academic commentary. Of greatest interest has been our treatment of interpretation issues. In that part, we support a formalist theory of contract interpretation. Our article has become the iconic formalist statement. As such, it has engendered a number of antiformalist responses. ${ }^{6}$

Recently, Professor Steven Burton has published a book on contract interpretation advancing a theory he calls "objectivism" that purports to resolve the divisions between these competing claims. ${ }^{7}$ In the course of developing his argument, Burton also discusses and rejects our approach. ${ }^{8}$ Instead, he purports to chart a reasonable middle course between the Scylla of contextualist theories of interpretation and the Charybdis of formalist interpretive theories. But in order to create this space, Burton mischaracterizes both formalist and anti-formalist arguments. The former, he claims, reduces to a "literalism" that urges the interpreter to focus only on a single word or phrase; the latter is a "subjectivism," that seeks to recover the parties' subjective intentions rather than the objective manifestations of those intentions. ${ }^{9}$

As we show in the analysis that follows, Burton's intermediate position is untenable. He urges courts to consider course of dealing and usage of trade evidence in addition to the contract and the parties' objective circumstances, but he would have courts exclude extrinsic evidence (such as prior negotiations) because these are too "subjective." Burton's solution thus precludes the

\footnotetext{
${ }^{6}$ See, e.g., James W. Bowers, Murphy's Law and the Elementary Theory of Contract Interpretation: A Response to Schwartz and Scott, 57 Rutgers L. Rev. 587 (2005); Juliet P. Kostritsky, Plain Meaning v. Broad Interpretation: How the Risk of Opportunism Defeats a Unitary Default Rule for Interpretation, 96 Ky L. J. 43 (2007-8); Jeffrey M. Lipshaw, The Bewitchment of Intelligence: Language and Ex Post Illusions of Intention, 78 Temple L. Rev. 99 (2005); Shawn J. Bayern, Rational Ignorance, Rational ClosedMindedness, and Modern Economic Formalism in Contract Law, 97 Cal. L. Rev. - (2009).

${ }^{7}$ STEVEn J. Burton, THE ElEMENTS OF CONTRACt InTERPRETATION (2009).

${ }^{8}$ Id. at $30,46,215-20$.

${ }^{9}$ Id at 1-6.

${ }^{10}$ Id at $78-81$.
} 
resolution of a dispute on summary judgment while it denies to parties a full trial in which all evidence that might reveal their ex ante intentions is considered. In short, his "objectivism" sacrifices both cost and accuracy - the two goals, we argue, that firms prefer the court to consider when interpreting their contract.

Professor Burton's response to our article, as well as a number of other responses, demonstrate that the interpretation debate has become both livelier and more highly contested than ever. Unfortunately, the responses to us often mistake or misconstrue our claims. To bring some clarity to the debate, therefore, we begin by restating the four arguments our article advanced. The first argument rests on the premise that, although accurate judicial interpretations ${ }^{11}$ are desirable, accurate interpretations are costly for parties and courts to obtain. If contract writing were free, parties could minimize interpretive error by exhaustively detailing their intentions. And if adjudication were free, courts could minimize interpretive error by hearing all relevant and material evidence. Contract writing and litigation are costly, however. Since no interpretive theory can justify devoting infinite resources to achieving interpretive accuracy, any socially desirable interpretive rule would trade accuracy off against contract writing and adjudication cost. Such a rule, we argue, tells courts in some cases to exclude relevant evidence. ${ }^{12}$

Our second argument follows from the fact that parties to commercial contracts have preferences over the rules courts use to interpret their agreements. These preferences exist because the parties are the primary beneficiaries of accuracy and the primary bearers of contract writing and litigation costs. Our second argument, then, rests on three premises: (i) courts that

\footnotetext{
${ }^{10}$ Id at $78-81$.

${ }^{11}$ An accurate interpretation recovers the parties' objectively manifested intentions as to their contractual objectives.

${ }^{12}$ In our 2003 paper, we assumed that, ceteris paribus, the more sources of evidence a court considers in resolving a dispute over interpretation the more accurate is the court's resolution of the dispute.
} 
interpret commercial contracts should share the parties' goal of maximizing expected contractual surplus; (ii) parties are better informed than courts about benefits and costs, so parties commonly have a comparative advantage over courts in making the requisite tradeoffs; and (iii) different contractual relationships may make different tradeoffs; that is, party preferences over interpretive rules are heterogeneous. Together, these premises imply that the state should defer to party preferences regarding interpretation, just as it defers today to party preferences over a contract's substantive terms, and that any rules the state adopts should be defaults. We argue, therefore, that the state should choose interpretive rules that conform to majoritarian party preferences, and courts should obey party instructions to depart from those rules in particular cases. Much of the criticism we face stems from the failure to appreciate this claim. Thus, we do not argue that the state should enact mandatory rules that require courts to make formalist interpretations. Rather, we argue that the state should create interpretative rules that instantiate party preferences; it is the business parties that commonly prefer formalist interpretations.

Our third argument urges participants in the interpretative debate to distinguish two principal interpretive questions: whether a contract term is ambiguous; and whether the term is written in the standard language or in a private language (e.g., technical terms in a trade). ${ }^{13}$ This distinction is important to draw because the categories of evidence a court should admit when making an interpretation arguably should turn on whether the issue involves ambiguity or language.

\footnotetext{
${ }^{13}$ Ambiguity is well understood but the language issue requires some elaboration. Assume, for example, that a contract requires the buyer to take "a minimum of 2,000 units." Under the standard language interpretation, the buyer would be in breach if he refused to accept more than 1,000 units. The buyer claims, however, that, in the parties' industry, the phrase "minimum" is an estimate, so that parties expect to renegotiate the contract quantity if circumstances materially change after the contract was concluded. The phrase "minimum" is clear in the standard language, and may be clear (to the parties) in the industry's language, but a dispute exists: should the court restrict its interpretive base to the standard language? Or should it admit evidence that the relevant term was written in the industry language?
} 
Our fourth argument, however, holds that the majoritarian party preference is textualist in both cases: business parties commonly prefer judicial interpretations to be made on a limited evidentiary base the most important element of which is the contract itself. ${ }^{14}$ With regard to ambiguity, we claim that parties prefer a narrow evidentiary base when a court has enough information to reach the "correct answer" to an interpretation question on average. Put more technically, the correct answer is the mean of the distribution of possible interpretations. The claim for textualism then follows because a risk neutral firm is indifferent to the magnitude of the variance around the mean; hence, this firm is unwilling to incur additional costs in order to increase the accuracy of any particular finding. With regard to language, we consider two defaults: a plain meaning default that supposes the parties to be communicating in the standard language; and a contextual default that admits extrinsic evidence that the parties were communicating in a "private" (technical) language. We argue that the preferred default should presume that parties have written in the majority language so as to reduce the risk of strategic behavior. A plain meaning default reduces this risk by requiring parties to specify the terms that take technical meanings. ${ }^{15}$ That parties have textualist preferences over questions of meaning supports our further claim that parties also have preferences over how a court determines the terms of a contract; that is, parties prefer courts to use a "hard" parol evidence rule, one that restricts courts to a narrow evidentiary base when identifying the contract's terms.

This Review Essay clarifies and extends the arguments sketched here. We briefly summarize empirical data that support our theory, and respond to our critics. With respect to the data, although much academic commentary suggests otherwise, both the available evidence and prevailing judicial practice support the claim that sophisticated parties prefer textualist

\footnotetext{
${ }^{14}$ This straightforward claim has been misunderstood by some critics. To clarify: by "the contract" we mean just that, an examination of the contested words or phrases in light of a reading of the contract as a whole, together with the pleadings and briefs describing the parties' performance under the contract. See infra text accompanying notes 30-31.

${ }^{15}$ Contract Theory at 584-90. Parties routinely define technical terms and particular meanings in extensive definition provisions in their written agreement. See infra text accompanying note 86.
} 
interpretation. ${ }^{16}$ Indeed, the majority of common law courts, led by New York, continue to follow the traditional Willistonian approach to interpretation, which embodies a hard parol evidence rule, retains the plain meaning rule, gives presumptively conclusive effect to merger clauses ${ }^{17}$ and, in general, permits the resolution of many interpretation disputes by summary judgment. ${ }^{18}$

In responding to our critics, we make three preliminary remarks. Initially, though our article was the first cut at a difficult subject, and so was less clear than it could have been, the mistakes in representing our view are hard to explain as resulting only from a lack of clarity on our part. "Formalism," to many, has come to represent almost every bad thing, ${ }^{19}$ so we as formalists are believed to commit almost every sin. Thus, we often are taken to be "literalists" who want to restrict an interpreting court to consider only the contract terms at issue and a dictionary. ${ }^{20}$ But

\footnotetext{
${ }^{16}$ For empirical support for the predictions of the theory, see infra text accompanying note 69-72.

${ }^{17}$ A merger or integration clause recites that all prior party understandings are merged into the final written agreement. See infra text accompanying note 67.
}

${ }^{18}$ See e.g., Kallman v. Radioshack Corp., 315 F.3d 731, 735-36 (7th Cir.2002) ("interpretation of the terms of an unambiguous contract is traditionally a question of law and is particularly suited to disposition on summary judgment"); Drake v. Hance, 673 S.E.2d 411 , 413 (N.C. Ct. App. 2009); Thrower v. Anson, 752 N.W.2d 555 (Neb. 2008) (same); See also, William C. Whitford, The Role of the Jury (and the Fact/Law Distinction) in the Interpretation of Written Contracts, 2001 Wis. L. Rev. 931, 938-952 (2001) ("[M]ost courts find that if the written terms have a clear or plain meaning, summary judgment is appropriate, and jury consideration of the meaning of extrinsic evidence is not necessary... the combination of a plain meaning rule and a hard [parol evidence rule] keep some cases out of the jury's hands altogether (i.e., permit disposition on summary judgment) in circumstances where alternative interpretive rules would require submission of the case to a jury.....").

${ }^{19}$ An illuminating article taking this line is Victoria Norse \& Gregory Shaffer, "Varieties of New Legal Realism: Can a New World Order Prompt a New Legal Theory?", University of Minnesota Law School Legal Studies Research paper No. 09-17 (2009).

${ }^{20}$ Professor Burton, in particular, claims that we are literalists: "The reason for rejecting them [our and Judge Posner's "economic" theories] is that the leading analysts' conclusions center strikingly on literalism as the preferred theory of contract interpretation." Burton, supra note 7, at 219 (footnote omitted). Professor Burton has taken the criticism of our formalism to an extreme. He claims that, under our view, "only the dictionary and the governing contract's words in the document may be taken into account [by a court]". Burton, supra note 7 , at 14. Literalism, as he describes it, urges courts to ignore both context and "the document as a whole;" 
literalism is impossible. Courts necessarily see the pleadings. When these are contested, a court will and should consider briefs and evidence as to what the parties did or failed to do, the damages the plaintiff claims, and so on. Rather, we argue that interpretive defaults acceptable to firms require courts to exclude particular categories of evidence when making interpretations, such as the parties' practice under prior contracts between them and their pre-contractual negotiations. ${ }^{21}$ Moreover, we concede that a court is more likely to make an accurate interpretation if it sees more evidence, but we argue that sometimes accuracy is not worth the costs of achieving it. Our critics reject this view largely on the ground that contextual interpretations are more accurate than formalist ones. This response does not engage our arguments, which importantly rest on cost concerns. $^{22}$

Second, critics claim that we advance a monist normative theory - economic welfare - to

rather, a literalist theory can restrict a court's attention to "a single word". Id. at 18, 37. We actually said: "[A] minimum evidentiary base is required for any coherent interpretation. This minimum base ... is composed of the parties' contract, a narrative concerning whether the parties performed the obligations that the contract appears to require, a standard English language dictionary ...." We also argued that parties would "invest resources in drafting until the writing is sufficiently clear" for a court to understand. Contract Theory at 577. Neither we, nor any theorist we know of, urges interpreting courts to restrict themselves to particular words or phrases in a contract.

${ }^{21}$ The default evidentiary base that parties prefer courts to exclude is constituted by (1) practice under prior agreements; (2) practice under the litigated agreement; (3) pre-contractual negotiations; (4) pre-contractual memoranda and other documents that are not attached to, or referred to, in the contract; and (5) custom. Contract Theory at 572 .

${ }^{22}$ Professor Burton, for example, does not mention the word cost in a book that has 221 pages of text. Other recent critiques also ignore or dismiss the relevance of costs. See sources cited in note 6, supra. An important exception is Richard A. Posner, The Law and Economics of Contract Interpretation, 83 Texas L. Rev. 1581 (2005). Professor Bayern briefly considers and rejects our cost concern in the settlement context. See Bayern, supra note 6 , at 132-35. He remarks that parties should settle contractual disputes with the same frequency whether courts use textual or contextual interpretive rules. However, if "at least one of the parties is irrationally optimistic about his chances of getting a favorable ('biased') interpretation from the court, then we would expect a rule that allows the maximal evidentiary base to be systematically better ... because, as the variance in the court's expected result decreases, there is simply less to be optimistic about...." Id. at 134. Hence, he argues, litigation costs are lower under a contextualist regime. It is difficult to know whether this argument is sound or not because neither we nor Bayern model the behavior of "irrationally optimistic" firms. Rather, we claim that "it is a plausible working assumption that firms rationally pursue" profit maximization. See Contract Theory at 551 and id. at note 18. Bayern does not seriously contest this assumption. 
govern a world that is too complex for any single theory. ${ }^{23}$ This criticism is misguided and incomplete. Our theory applies to contracts between sophisticated firms. It is a questionable theory if the world of sophisticated firms that we analyze is too complex for the theory. But it is not a questionable theory if only the wider world is too complex. Further, this criticism confuses procedural with substantive norms. Professor Burton thus criticizes our theory as excessively monist because, he alleges, we neglect the rule of law virtues of security of transactions, nonarbitrary adjudications and administrability. ${ }^{24}$ Rule of law virtues are "procedural", in the sense that the virtues create a framework in which decision makers should implement the substantive norms the decision makers prefer. The virtues, however, do not indentify the substantive norms that are to be implemented. For example, a norm requiring courts to avoid arbitrary decisions does not identify the norms that courts should apply in principled ways. If a theory is pluralist when it combines the procedural virtues of the rule of law with a single substantive norm, then we have a pluralist theory; for we actually argue that our theory better serves the procedural virtues Burton identifies than other theories do. ${ }^{25}$

Our theory is monist in a substantive sense. We argue that the contract law that regulates transactions between firms should seek only to maximize efficiency. This argument rests on two grounds. First, efficiency is the only implementable norm when firms prefer efficient rules and have the resources and sophistication to contract out of rules they dislike. ${ }^{26}$ Second, scholars have yet to show how the efficiency norm can be combined with other substantive norms to yield predictable that is, non-arbitrary - adjudications. In the absence of such a showing, substantively pluralist

\footnotetext{
${ }^{23}$ See e.g., Burton, supra note 7 , at 214-218.

${ }^{24}$ Id. at $216-217$.

${ }^{25}$ For discussion of our views on interpretation and procedural values, see Contract Theory at 584-90; for default rules, see id. at 594-609.

${ }^{26}$ See Contract Theory at 596; Alan Schwartz, The Default Rule Paradigm and the Limits of Contract Law, 1 So. Cal. Interdisciplinary L. J. 390, 402-03 (1993).
} 
theories necessarily serve the rule of law virtues less than well than substantively monist theories do. These two grounds cannot be dismissed on the mere assertion that the world is too complex for a single theory.

Finally, critics claim that we offer a "law and economics account" that may be appropriate for law and economics scholars but which need not be considered by courts or scholars of other persuasions. ${ }^{27}$ This is an evasion, not an argument. We claim that interpretive rules should reflect the preferences of business firms that contract with each other. We justify this claim largely on welfare grounds and use economic analysis to identify the preferences that business firms typically hold. Such a law and economics account is either persuasive or it is not. Hence, it is open to critics to (a) explain why interpretation rules for firms should not be based on party preferences; or (b) show that we have misapplied economic theory; or (c) show that an alternative methodology would better recover what business parties prefer. ${ }^{28}$

The Review Essay proceeds as follows. In Part II we further clarify our argument for textualist interpretation. Part III then applies that argument to the claims of our critics. In Part IV, we show how the law can, and often does, implement a textualist interpretive theory. Part V briefly concludes

\footnotetext{
${ }^{27}$ This view often is expressed at conferences whose members are methodologically diverse. An unusually candid written statement is Burton, supra note 7 , at 16. More commonly, articles proceed as if law and economics analyses do not exist.

${ }^{28}$ When individual persons are parties to transactions, cognitive psychology and behavioral economics are useful in explaining contracting behavior. For recent efforts by one or the other of us along these lines, see $\mathrm{M}$. Keith Chen \& Alan Schwartz, "Intertemporal Choice and Legal Constraints,"(SSRN 2009); Alan Schwartz, How Much Irrationality Does the Market Permit?, 37 J. Legal Studies 131 (2008); Robert E. Scott, A Theory of Self-Enforcing Indefinite Agreements, 103 Colum. L. Rev. 1641 (2003); Robert E. Scott, The Limits of Behavioral Theories of Law and Social Norms, 86 Va. L. Rev. 1603 (2000). For an effort to combine economic and philosophical insights, see Daniel M. Markovits \& Alan Schwartz, "The Dual Performance Hypothesis and the Myth of Efficient Breach"(mimeo 2009).
} 


\section{The Interpretation Problem}

\section{A. The Timing and Nature of Interpretation Issues.}

Interpretation issues can be illuminated by first considering the timing of a simple game:

$t^{0}$ : The state chooses the rules that govern contractual interpretation.

$t^{1}$ : The parties write a contract to trade a performance for a price. The contract describes the performance that is to be traded (e.g., manufacture a machine or construct a building); sets out the parties' procedures (i.e., when the performance is to be tendered; when the buyer is to pay); and sets a price and mode of payment. The contract also may set out the interpretive rules the parties prefer a court to use if (a) the state's rules are defaults; and (b) the parties prefer their own rules to the state's rules.

$t^{2}$ : The parties learn the state of the world.

$t^{3}:$ (a) The seller decides whether or not to perform; (b) If the seller chooses performance, the buyer decides whether or not to pay.

$t^{4}$ : If the seller decides not to perform when the buyer prefers to trade the performance for the contract price, the buyer sues; if the buyer refuses to pay when the seller tenders performance, the seller sues.

$t^{5}:$ A court resolves disputes.

These disputes may raise interpretive issues. For example, the seller may reject the proposed trade on the ground that the deal was for cash but the buyer instead insisted on credit. Alternatively, the buyer may refuse to pay on the ground that the seller failed to tender the quality of performance that the contract required. To resolve these disputes, a court must either apply the interpretive rules that the state promulgated at $t^{0}$ or, if the state's rules are defaults, apply any interpretive rules the parties substituted at $t^{1}$. 
The interpretive rules that the court applies at $\mathrm{t}^{5}$ largely regulate the admissibility of evidence. Assume, for example, that a plaintiff buyer proffers the following evidence in support of his claim that the seller delivered goods of the wrong quality: (a) the product the seller delivered; (b) the written contract that contains the specifications for the product; (c) two pre-contractual memoranda the parties exchanged that referred to the contract specifications; and (d) an oral narrative of party conversations prior to signing the contract that concerned the contractual quality standard. An interpretive rule selects the evidence that is admissible to resolve the interpretive question. A textual rule admits evidence "bits" (a) and (b) but excludes bits (c) and (d). A contextual rule admits (c) and sometimes (d).

\section{B. The Problems the State Must Solve.}

The timing sequence set out above focuses attention on the three questions that the state must answer at $t^{0}$ so that the court can resolve an interpretation contest at $t^{5}$. The relevant "state" consists of three separate legal sources: the Uniform Commercial Code, the Restatement (Second) of Contracts and the decisions of common law courts. The questions are: First, what goals should the state's interpretive rules attempt to implement? Second, what content rules best implement these goals? Third, should the rules be mandatory or defaults?

Regarding the first question, a state can have both first and second order preferences over goals. ${ }^{29}$ We focus on first order preferences in this Essay. The first order interpretive preference of each of the three sources of law is "goal neutral:" it is uniformly held that a court resolving an interpretive dispute should recover the parties' intentions, whatever those intentions were. Intention, in turn, is determined prospectively and objectively; that is, the question for the court is what manifestation of intent a counterparty could reasonably understand the other was assenting to

${ }^{29}$ A first order preference implies the choice of an interpretive rule; a second order preference resolves ties. For example, one state may prefer efficient interpretive rules. Another state may prefer distributionally fair rules. When it is unclear which interpretation of a contract is efficient, the former state would prefer the distributionally fair interpretation if it has a second order preference for distributional fairness. Similarly, the latter state may have a second order preference for efficiency, and so choose the efficient interpretation when it is unclear which interpretation is fair. 
when it contracted. ${ }^{30}$ Goal neutrality is justifiable under the freedom of contract norm. If parties can create their own contract, the interpreter's role is restricted to finding out what that contract was. The interpretive rules, therefore, should facilitate this quest. ${ }^{31}$

The second question the state must resolve at $\mathrm{t}^{0}$ is to determine which legal rules best implement the goal of recovering the parties' intentions. Here the consensus of the three sources of controlling law breaks down. On one view, a goal neutral preference to recover the parties' intentions is best implemented on a broad evidentiary base. The interpretive rules therefore should be contextualist. On the other prevalent view, courts commonly can recover the parties' intentions on a narrower evidentiary base. The interpretive rules thus should be textualist. The (almost) scholarly consensus shares the UCC and Restatement view that the appropriate first order interpretive preference should be goal neutral (i.e., the court should recover the parties' intentions); and that this preference is best implemented by permitting the court to access a broad evidentiary base in determining both the terms of the contract and the meaning to be attached to those terms. ${ }^{32}$

\footnotetext{
${ }^{30}$ See Restatement (Second) of Contracts $\$ 201$ ("Where the parties have attached different meanings to a promise or agreement or a term thereof, it is interpreted in accordance with the meaning attached by one of them if at the time the agreement was made...(b) that party had no reason to know of any different meaning attached by the other, and the other had reason to know the meaning attached by the first party.) See note 75 infra.

${ }^{31}$ The search for intention, even if defined objectively and prospectively, is more difficult than is commonly believed. Courts typically identify contractual intent with the parties' contractual objectives -- the contractual ends of their agreement. But reaching agreement on a shared objective is only one aspect of a shared intention. The parties must also create the particular rights and duties that will serve as their contractual means for achieving their shared ends. In other words, parties can have a shared intention about how their ultimate intentions are to be achieved. Courts frequently conflate the parties' contractual means with their contractual ends. By doing so, they can inadvertently reduce the range of contractual arrangements to which contract law gives effect, thereby potentially depriving commercial parties of essential tools for contract design. For discussion, see Jody S. Kraus \& Robert E. Scott, Contract Design and the Structure of Contractual Intent, 84 N.Y.U. L. Rev. (Oct. 2009).

${ }^{32}$ Those who argue for mandatory contextualist interpretations often justify such rules as necessary to prevent exploitation of unsophisticated individuals, susceptible to cognitive biases, who enter into written contracts with sophisticated parties who supply written contract terms that alter previously settled understandings. See
} 
To understand the litigation implications of these competing views, consider the key differences between hard and soft versions of the rules governing, respectively, parol evidence and the meaning of terms. The parol evidence rule functions to determine the terms of the contract. A hard or textualist parol evidence rule thus narrows the evidentiary base ${ }^{33}$ the court considers when finding the contract's terms; a soft or contextualist rule expands the base. A separate question asks: what do the contested terms mean? This issue arises when a term in the written agreement has a plain, unambiguous meaning in the standard language, but one party claims that the parties attributed a different meaning to the term. ${ }^{34}$ Courts that follow a hard parol evidence rule also tend to follow the plain meaning rule, and thus exclude extrinsic evidence to resolve such disputes. Courts that follow a soft parol evidence rule also tend to reject the view that words have invariant meanings; hence, these courts permit a party to introduce extrinsic evidence of the particular - i.e., nonstandard - meaning that the parties attached to the contract language.

The final question that the state must resolve is whether its interpretive rules should be mandatory or defaults that parties are free to alter. Just about everyone who creates, applies or analyzes the interpretive rules believes that they should be mandatory. ${ }^{35}$ And, in fact, the rules are

e.g., Masterson v. Sine, 436 P. 2d 561 (1968) ("[T]the party urging the spoken as against the written word is most often the economic underdog, threatened by severe hardship if the writing is enforced."). Even assuming that these concerns are valid reasons for imposing a mandatory contextulist regime in contracts between individuals and firms, they do not apply to the firm to firm negotiated contracts that are the focus of our theory.

${ }^{33}$ Recall that in parol evidence contests the issue turns on whether the parties intended the written agreement to contain all the terms of the contract or whether the parties intended the contract to consist of other terms, such as prior understandings or relevant usages in addition to those in the writing. For discussion, see ROBERT E. SCOTT \& JODY S. KRAUS, CONTRACT LAW \& THEORY 54 1-6 (4 ${ }^{\mathrm{TH}}$ ED. 2007).

${ }^{34}$ This claim could be based on the argument that other sources of evidence-such as the parties prior negotiations-show that the written term is ambiguous, or that those other sources show that the parties attached a specialized or private meaning to the term in question. See e.g., Pacific Gas \& Electric Co. v. G.W. Thomas Drayage \& Rigging Co. 442 P. 2d 641 (Cal. 1968).

${ }^{35}$ See, e.g., Burton supra note 7 , at 193-202. 
mandatory in the sense that parties cannot contract directly for textualist or contextualist interpretive rules. Textualist and contextualist courts differ, however, in the degree to which they permit parties indirectly to control how disputes over their contract are adjudicated. For example, textualist courts apply a hard parol evidence rule, but this version of the rule permits parties to "contract out" either by not integrating their writing fully or by including context evidence in the integrated contract. In contrast, contextualist courts apply an invariant soft parol evidence rule, so that parties cannot narrow the evidentiary base. In contextualist jurisdictions, therefore, contextualism is the only option. ${ }^{36}$

\section{An Introduction to Our Theory of Interpretation.}

\section{The case for party control}

We introduce our theory here, and extend it as required in the course of this Review Essay. ${ }^{37}$ We now assume for purposes of discussion that interpretations should be goal neutral; the state should seek to recover the parties' objective ex ante intentions. Before discussing the interpretive rules that this goal implies, we note two related questions—ambiguity and language- that the rules must answer. Some terms are ambiguous because they can take more than one objective meaning. For example, if a seller agrees to sell "one Ming vase" to a buyer, but the seller owns four Ming vases, the term "one Ming vase" is ambiguous because it could refer to any of the four vases; the phrase does not identify the vase that the parties intend to trade. Other terms are ambiguous in a different sense: because they are vague, they cannot precisely confine the parties' meaning. Consider a contract to sell "hard, dark red Macintosh apples." The terms "hard" and "dark red"

\footnotetext{
${ }^{36}$ Everyone agrees that the parol evidence rule should permit parties to exercise control over the evidentiary base by either expanding or contracting the sources of evidence used to identify the contract terms. Courts that apply a soft parol evidence rule, however, deny presumptive effect to merger clauses and reject the four corners rule under which a written contract that appears complete on its face is held presumptively fully integrated with respect to its terms. In consequence, soft parol evidence rules are effectively contextualist. The same point holds for the rules governing the meaning of terms. We expand these points in Part IV.

${ }^{37}$ Recall that our theory holds only for the interpretation of contracts between business firms. Contract Theory at 544-47. Throughout this Review Essay, we refer to the firm to firm contractors in this "sub-world" as "parties" without further elaboration.
} 
are vague because they do not precisely determine what constitutes a conforming apple: how hard and how dark red must the apples be? In both instances of ambiguity, the interpreting court may be unable to recover the parties' intentions on a narrow evidentiary base. ${ }^{38}$

As an example of the language question, consider an acquisition agreement that excuses the buyer if the target seller suffers a "material adverse change" that substantially reduces its value. A sudden shortage of parts disrupts the seller's production. As a consequence, the seller's market capitalization drops substantially. An ordinary observer likely would think that the parts shortage constituted a material adverse change. The seller, however, argues that, in the market for corporate control, a material adverse change is understood to denote a reduction in the seller's value that the seller could have prevented, and it could not have prevented the parts shortage. ${ }^{39}$ Did the parties want the phrase "material adverse change" interpreted as ordinary speakers of English would understand it? Or did the parties want the phrase to be interpreted as participants in the market for corporate control would understand it?

We argue, for various reasons, that the interpretive rules that regulate both types of meaning question should be defaults. ${ }^{40}$ This argument has two implications. First, the rules should

${ }^{38}$ SCOTT \& KRAUS, supra note 33 at 543-44. Courts generally do not distinguish between "vague" and "ambiguous" terms and we follow that convention here. A typical judicial definition of ambiguity includes, for example, any term or word that is "capable of more than one sensible and reasonable interpretation or has no definite significance." Ross Bros. Constr. Co. v. State ex rel Transp. Comm'n Highway Div. 650 P.2d 1080 (Or. 1982). For discussion of the variety of contract writing errors that parties make, see Charles J. Goetz \& Robert E. Scott, The Limits of Expanded Choice: An Analysis of the Interactions Between Express and Implied Contract Terms, 73 Calif. L. Rev. 261, 265-73 (1985).

${ }^{39}$ Support for an argument of this type may be found in Ronald J. Gilson \& Alan Schwartz, Understanding MACs: Moral Hazard in Acquisitions, 21 J. L. Econ. \& Org. 330 (2005).

${ }^{40}$ We illustrate our claims here using the ambiguity question, on which most of our critics focus. Regarding the language issue, we argued earlier that the default should take parties to have written in the majority language because this would reduce strategic behavior. Under the alternative default, a party who wants to exit what has turned out to be a bad deal can easily create an interpretive dispute by claiming that a clear term 
reflect majoritarian party preferences. Second, courts should obey party interpretive instructions that alter the defaults. As an example of the latter implication, parties should be free to choose a hard rule to govern parol evidence questions if the default is soft, and the converse if the rule is hard. In contrast, many courts and most commentators assume that a goal neutral interpretive regime requires mandatory interpretive rules. This assumption is rarely defended. Our article contested this assumption by arguing that: (a) the rules should reflect the parties' preferences; and (b) parties prefer textualist interpretive defaults.

As we noted above, critics primarily attack our claim for textualist rules but essentially ignore the logically prior claim that the rules should be defaults that reflect party preferences. This is unfortunate because the argument for interpretive defaults is the more important claim. Critics defend contextualist rules primarily on the ground that contextualism yields more accurate interpretations than textualism. This defense is not responsive. If the interpretive rules that a goal neutral interpretive theory implies should be defaults, and if good defaults reflect party preferences, the search cannot be for the most accurate rules, simpliciter. Rather, the search must locate the most accurate rules that parties are willing to pay for. One can refute our view, therefore, only by showing that a goal neutral interpretive theory better supports the case for mandatory rules than the case for defaults; or by showing that parties would reject the defaults that we identify.

We begin here by reviewing and extending the case for interpretive defaults. ${ }^{41}$ Note first that no interpretive theory can entirely ignore costs. A multi-year trial to resolve a dispute over the meaning of a contract is unacceptable to all. Three cost categories are relevant to interpretation (a) the court's opportunity cost: the more time the court spends on a particular interpretive issue,

has a different meaning in the parties' private language. Parties wishing to avoid this possibility must contract to exclude all of the possible private languages from the evidentiary base if there is a dispute. It is more efficient to suppose that parties wrote in the majority language, so that they need only opt into the particular technical language they want to use (supposing them to prefer any such language). Contract Theory at 584-90.

${ }^{41}$ In Part III we attempt to refute criticisms of the defaults we identify. 
the less time it can spend on other issues or other cases; (b) the parties' contract writing cost, which partly is a function of the interpretive rules; and (c) the parties' enforcement cost. We focus on the latter two cost categories for two reasons. First, the state does not appear to take court costs into account when it chooses interpretive rules. Second, as we argue below, parties rarely prefer more evidence than courts prefer, and usually prefer less. Hence, the danger that parties will overwhelm courts with interpretive tasks is slight.

There would be no need for defaults or interpretive instructions (from parties to courts) if two premises were satisfied: first, the state's goal is to maximize the parties' expected profits; and, second, the state is as capable as the parties in doing so. Then the state could adopt optimal interpretive rules. These rules would direct the court to broaden the evidentiary base when this would maximize the parties' expected utility and to narrow the base when that would be best. Parties would anticipate that courts would interpret disputes according to these rules and thus would not issue interpretive instructions (there is no need to instruct a perfect agent). The case for defaults (and instructions) thus begins with the recognition that neither of the premises holds.

Assume, initially, that the state does share the parties' surplus maximizing goal. ${ }^{42}$ Nevertheless, the second premise cannot be satisfied: the state is less capable than parties at identifying optimal interpretive rules because the state is less well informed than parties about contract writing and enforcement costs and the benefits that correct interpretations produce. Thus, even a state that shares the parties' goal will sometimes mistake the optimal tradeoff between accuracy and cost. The interpretive rules thus should tell the court to follow party instructions regarding the evidentiary base when the contract contains instructions. The rules, that is, must be defaults. $^{43}$ But of course, as noted above, the state does not share the parties' surplus maximizing

\footnotetext{
${ }^{42}$ We urge the state to adopt this goal for business contracts.

${ }^{43}$ It may be helpful to expand this point. The terms in a commercial contract perform two functions. They describe what the parties intend to trade, and they create incentives for parties to maximize expected surplus.
} 
goal; rather, as noted above, the state is goal neutral. This raises a further question: Can interpretive rules that require greater accuracy in interpretation than the parties prefer be justified under a goal neutral interpretive theory? The apparent answer is no. Goal neutrality gives the parties control over the substantive terms of the contract. It takes an argument to reject the obvious implication that the parties also should have control over the rules that determine how those terms are identified and understood.

A number of courts that pursue goal neutrality actually do put more weight on accuracy in recovering the parties intended purposes than do typical parties. This judicial preference for accuracy largely rests on libertarian grounds. Some courts are reluctant to impose the state's coercive power on a reluctant party unless the court is relatively certain that the party failed to do what the contract required. Courts implement this libertarian value without serious constraint because judges do not internalize the costs of pursing this preference: the judges do not observe the parties' contract writing costs and only imperfectly observe their litigation costs. In addition, judges do not bear the consequences of rules that require parties to bear costs the parties would prefer to avoid.

The price divides this surplus. As interpretive accuracy increases, the incentive effect of the terms increases. An efficient interpretive rule thus encourages parties to describe their intentions clearly, and to introduce context evidence at trial when this would better improve judicial accuracy. As said above, however, contract writing cost is positive and litigation cost is positive. Hence, an efficient interpretive rule would maximize an expression such as the following: $\max _{t, c} \sum_{k=1}^{\infty}[u(k)-\operatorname{pr}(k(t)-k c]$

Here $\mathrm{k}$ is an individual contract; $\mathrm{t}$ is trial cost and $\mathrm{c}$ is contract writing cost. The first term in the summation is the benefit of contracting in creating good incentives for the parties; the second term is the expected trial cost (the probability that the contract will raise an interpretation issue that requires more than the minimum evidentiary base to resolve); the third term is the cost of writing a contract. We argue that parties commonly can solve this maximization problem better than courts because parties are better informed about the benefit term and the two cost terms. Hence, while an ideal adjudicator can be trusted to solve this problem for society, efficiency minded courts should solve the problem only when parties do not instruct them. A more formal analysis of interpretation along these lines is in Alan Schwartz \& Joel Watson, "Describability and Contract Interpretation" (manuscript 2009). 
This observed preference of some courts for more accuracy than parties prefer is not sustainable under the norm of goal neutrality. A court's reluctance to coerce parties is misplaced if parties are not reluctant to impose coercion on themselves. Sophisticated parties now can waive the right to a jury trial, or even the right to a trial in court, so they seemingly also should be able to waive the protection of exhaustive interpretative hearings. And, while it is a fact that courts do not internalize the costs of contract writing and evidence production, that is not a reason for the court to override party preferences. Because parties are more sensitive to costs than courts, parties rarely prefer courts to admit more evidence than courts want to hear, and usually prefer courts to admit less. ${ }^{44}$

We can now summarize our claim that interpretation rules should be defaults. A major task of any interpretive theory is to recover the parties' contracting intentions. As said, no defensible theory supports requiring courts and parties to devote infinite resources to this task. Therefore, any theory "on the ground" must trade off the gains from increased accuracy in interpretation against the costs. Contracting parties have a comparative advantage over the state in choosing the interpretive rules that best make this tradeoff because the parties are better informed than the state about the relevant costs and benefits. It follows that courts should yield to the parties' preferences over the rules unless the state is pursuing an interpretive theory that is animated by a goal that requires greater accuracy than parties prefer. We have just argued that the case for greater accuracy cannot rest on the efficiency norm or on goal neutrality. So far as can be known, the state is not pursuing a goal other than these. It follows that there is no good reason to deny parties as much control over the interpretive terms of a contract as parties now have over the substantive terms.

\section{Parties prefer textualist defaults}

\footnotetext{
${ }^{44}$ We refer here to parties' ex ante preferences. Conflicts can arise in litigation because parties have strategic reasons to disagree on evidence production.
} 
We summarize a complex argument with a simple example. ${ }^{45}$ Assume that an agreement requires a contractor to construct a particular structure. The parties later do not contest what the contractor actually did-how many rooms the completed structure had, the thickness of the walls, and so forth. The issue is whether the contractor created the structure that the contract required.

We denote a conforming structure with the letter $\mathrm{S}^{*}$ : this structure has the attributes the parties intended. The buyer's payoff, if the seller complied, is represented as the value of $\mathrm{S}^{*}$ : that is, $\mathrm{v}\left(\mathrm{S}^{*}\right)$. Assume now that the buyer claims, correctly, that the completed structure has fewer attributes - is less desirable - than $\mathrm{S}^{*}$ would have been. We denote such a nonconforming structure as $\mathrm{S}^{-}$, so that the structure yields the buyer a value of $\mathrm{v}\left(\mathrm{S}^{-}\right)$. The seller concedes that she erected the structure $S^{-}$, but argues that this performance was all that the contract required: in the seller's view, $\mathrm{S}^{-}$actually is the $\mathrm{S}^{*}$ the contract described. If the court accepts the seller's erroneous interpretation, the buyer must pay the price and so he realizes less value $\left(v\left(S^{*}\right)-v\left(S^{-}\right)\right)$than he contracted for. Alternatively, suppose that the seller actually complied by delivering the structure $\mathrm{S}^{*}$, but the buyer claims that the contract called for an even better structure. We denote this structure as $\mathrm{S}^{+}$, which, had it been delivered, would have yielded the buyer a value of $\mathrm{v}\left(\mathrm{S}^{+}\right)$. If the court accepts the buyer's erroneous interpretation, the buyer can reduce the price by his claimed "loss": $v\left(\mathrm{~S}^{+}\right)-\mathrm{v}\left(\mathrm{S}^{*}\right)$.

We motivate this example with two assumptions. First, parties prefer interpretations not to be random or perverse. Specifically, parties contract such that courts will make the correct interpretation more often than courts err when courts see the contract, the seller's performance and the pleadings. Second, courts are unbiased. A court is as likely to err on the high side, finding that the contract required the seller to produce the $\mathrm{S}^{+}$structure, as it is likely to err on the low side, finding that the contract only required the seller to produce the $\mathrm{S}^{-}$structure. ${ }^{46}$ Therefore, in our

${ }^{45}$ A complete statement is Contract Theory at 573-84.

${ }^{46}$ Professor Bayern rejects our argument on this point but here he is mistaken. See Bayern, supra note 6, at 
illustration, parties believe that an interpreting court is more likely to find that the contract required the seller to erect the $\mathrm{S}^{*}$ structure than that the contract required the parties to erect either the $\mathrm{S}^{-}$ or the $\mathrm{S}^{+}$structure.

Our motivating assumption that courts will make the correct interpretation more often than not on the evidentiary base we identify is supported by the fact that parties contract in anticipation of what the court will see. Hence, if a court will only see limited evidence, the contract will be more detailed than if the court will see all available evidence. Parties prefer correct interpretations, and so they will write contracts, as far as costs permit, to ensure correct outcomes. Thus, a court

121-23. He considers an arbitrary distribution of numbers (from -3 to 3 ) from which a court can pick. The midpoint is zero. He then takes us to claim that the expected value of the court's pick is zero because there is no more reason to believe that the court will pick a higher number than zero than that the court will pick a lower number. But, he says, there is no more reason to believe that the court will pick a number higher than two than lower than two either. Bayern's argument holds for numbers because he implicitly assumes that his number distribution is uniform. The probability of any particular outcome materializing from a uniform distribution is the same as any other outcome materializing. For example, the midpoint of a uniform distribution ranging from zero to one is .5. Beginning at zero, the probability that an outcome equals .1 is the same as the probability that the outcome equals .2, and so on. Now consider a normal distribution (think of a bell shaped curve). The midpoint of this distribution is the most likely probability. The curve describing the distribution is rising until the curve reaches a maximum because the relevant graph plots probabilities on the vertical axis and values on the horizontal. Therefore, starting with zero, the probability that an outcome equals, say, .1 is less than the probability that the outcome equals .2 Similarly, the probability of outcomes declines as one moves past the maximum. We argued that the space of interpretive outcomes is normally distributed. Normality is implied by our two assumptions. If the court is more likely to be right than to be wrong, then the curve describing the interpretation space has a unique maximum at the correct interpretation. If the court is unbiased, then this curve is symmetrical. A normal distribution is symmetrical with a unique maximum. Moreover, our assumptions are supported by the observation that (a) parties want to maximize the probability that the court will draw the correct interpretation from the space of interpretations; and (b) parties have some control over the outcome because they write the contract that the court later will interpret. Thus, we say: "It is optimal for risk-neutral firms to invest resources in drafting until the writing is sufficiently clear ... so that the mean of the distribution of possible judicial interpretations is the correct interpretation .... Firms will attempt to write contracts with sufficient clarity to permit courts to find correct answers, though with error." Contract Theory at 577. It would be irrational of parties to prefer the space of interpretive outcomes to be uniform. To see why, suppose the space of outcomes is uniformly distributed between zero and one, and the correct interpretation is described by the number 4 . Then, the probability that the court will interpret the contract to realize the outcome 4 is only $10 \%$ because every outcome is equally likely. The court is effectively random. Parties who prefer random courts would not incur the costs of putting description information in their contracts, but real parties always do. Bayern's example thus is irrelevant to the interpretation debate because it implicitly and erroneously assumes that the space of interpretive outcomes is uniformly distributed. 
is more likely to make the correct interpretation than any other interpretation on an evidentiary base that is composed of the parties' narrative, revealed by the pleadings and briefs, the contract, and the court's knowledge of the world. We further assume courts are unbiased because, in commercial cases, there is no reason to believe that the typical judge has a systematic preference for one or the other litigant. Rather, courts are goal neutral. Finally, we assume that the broader the evidentiary base, the closer the court is to making the correct interpretation. In the illustration above, then, $\mathrm{S}^{-}$and $\mathrm{S}^{+}$are likely to be closer to $\mathrm{S}^{*}$ for a contextualist court than for a textualist court. Using the technical term, more evidence shrinks the variance around the true interpretation. An infinite amount of evidence reduces the variance to zero.

This analysis should clarify the accuracy/cost tradeoff we described above. When parties contract, they know that they can induce interpretations that are accurate on average - the most likely outcome is $\mathrm{S}^{*}$ - when a later court sees relatively little, and they also know that they can restrict interpretive outcomes to be ever closer to $S^{*}$ as the court sees more and more. On the other hand, the more the court sees, the more costly contract writing and evidence production become.

Our central claim is that business firms put major weight on costs. These firms are commonly assumed to be risk neutral. Firms are concerned that the mean of a distribution of future values turns out to be "true," but the firm is unconcerned with variance. In other words, there is a "risk" that a court will locate $\mathrm{S}^{-}$and $\mathrm{S}^{+}$far from $\mathrm{S}^{*}$, but risk neutral firms accept that risk. Thus, the firms in our analysis spend enough, in contracting and litigation costs, to ensure a true mean: the most likely interpretation of their contract will correctly require the seller to deliver $\mathrm{S}^{*}$. The parties prefer, however, not to obtain interpretations that are very close to $S^{*}$ because these would be too costly. 
To be sure, this argument has limits. When a correct interpretation is particularly important, say the interpretation of a new contract that is expected to be widely used, a party may prefer a court to hear all the available evidence. Similarly, parties dislike infinite variance and will spend some money to keep interpretations in the (sometimes wide) range of the plausible. Thus, we argue for defaults under which the court makes interpretations on a minimum evidentiary base. Parties who want more evidence than this can contract out. In sum, we claim that interpretive rules should be defaults, and that the defaults should be textualist. We next defend this second claim against the most important objections.

\section{Engaging the CRITics}

In Part II we discussed what may be called abstract or general criticisms of our theory. This Part discusses four concrete objections: (1) firms are not risk neutral; (2) unbiased interpretations can encourage strategic behavior; (3) the evidentiary base we claim that parties prefer is too narrow to sustain accurate interpretations, so parties free to choose would reject the rules we propose; and (4) there is no evidence that actual parties possess the preferences we attribute to them. We discuss each objection in turn.

\section{A. Risk Neutrality}

Anti-formalist critics contest our claim that firms are risk neutral. ${ }^{47}$ This criticism is misplaced because these critics do not contest our claim that firms maximize expected profits. Profit maximization implies risk neutrality. ${ }^{48}$ A risk neutral firm acts "as if" it is risk averse only

${ }^{47}$ See, e.g. Bayern, supra note 6 , at 113,n. 31 and 124, n 60; Bowers, supra note 6 at 598.

${ }^{48}$ This note is for generalists. The declining marginal utility of money theory holds that individuals have strictly concave utility functions. In lay language, this means that the first dollars a person receives will generate a great deal of utility; these dollars will purchase food and shelter. More dollars than this satisfy ever less urgent needs, so that a well off person ultimately is choosing among brands of champagne. That the 
when it is willing to incur costs to reduce variance in the space of contractual interpretations. We noted above, and explained more fully in our paper, that firms act in this way when a correct interpretation is particularly important to them. ${ }^{49}$ Few business contracts have this "bet the ranch" character, however. Thus, we make risk neutrality the premise when analyzing the preferences of firms

\section{B. Strategic Behavior}

Critics fault our interpretive theory for encouraging parties to engage in strategic behavior, either by acting opportunistically ${ }^{50}$ or by "chiseling" on their obligations. ${ }^{51}$ An unbiased court nevertheless may issue an interpretation that is wide of the mark, and the possibility of large errors, the claim goes, creates an incentive for parties to cheat. Professor Bowers concisely summarizes this claim: "If a party thinks there is a good chance that its chiseling behavior will be protected by an erroneous contract interpretation, the more chiseling will tend to

marginal utility of a dollar declines as the person has more dollars implies that individuals weigh losses more heavily than gains. A gain adds to wealth while a loss detracts from it. Individuals thus are not "neutral," say, between a .5 chance to earn a dollar and a .5 chance to lose a dollar. The gain would yield less utility than the loss would take away. People thus must be paid to bear risk. It is otherwise with firms that maximize profits. These firms have linear utility functions. Each dollar of additional profit counts as much for the firm as does the prior dollar. Since firms care only about money, a firm is "neutral" between a 5 chance to earn a dollar and a .5 chance to lose a dollar. Such a firm also is neutral between a .5 chance to earn $\$ 10,000$ and a .5 chance to lose $\$ 10,000$. The latter gamble has a very much greater variance than the former gamble. This is why we say that firms care much more about the mean - they prefer higher expected values to lower - than they care about the variance.

${ }^{49}$ See Contract Theory at 576-77.

${ }^{50}$ Kostritsky, supra note 6 at 58; Bayern, supra note 6 at 130, 134, n.81.

${ }^{51}$ Bowers, supra note 6 at 601 .

${ }^{52}$ Id. at 601 . To "chisel" is to supply less than the performance the contract required, but to claim that the performance is compliant, so that the promisor is entitled to the full price. 
This is a significant objection. As we have said, parties write contracts to give themselves incentives to take maximizing actions. If parties behave strategically when courts are only right on average, the incentive function of a contract may be vitiated; that is, a party may take the chiseling rather than the maximizing path. If this danger is real, parties would prefer contextualist interpretations, which shrink variance and thus reduce the strategic behavior risk.

The objection is unpersuasive, however, because the incentive of a party to behave strategically is small when courts are right on average. To see why, we use the example that involved contracting for a particular structure. Consider the seller's incentives after the contract is signed. The seller knows that if there is a dispute and if interpretation is textualist, the court will later see the contract, the pleadings and the performance the seller rendered. The court will evaluate this data using its experience. ${ }^{53}$ For the reasons given above, we assume that the parties' contract is written such that the court is likely to make the correct interpretation more than half the time. On this view, "probability mass" encourages compliant behavior. The seller knows that the court will make a correct interpretation with probability greater than one half, and that it will incorrectly find that the contract required the seller to tender a performance of lower quality than the contract required with a lesser probability. In both cases, a seller who complies - who supplies the $\mathrm{S}^{*}$ structure - will receive her expectation (the court believes that the seller either complied or over-complied). The seller would erroneously have to pay damages only if the court finds that the

\footnotetext{
${ }^{53}$ Professor Burton believes that the "interpreter's experience and understanding of the world ... should be excluded in principle" because the rule of law virtues require exclusion and because the parties do not "want the resolution of their disputes to turn on" the interpreter's identity. Burton, supra note 7 at 37 . The former claim requires more argument than Burton provides. For example, the rule of law virtues are thought not to be violated even though the fate of a criminal defendant is importantly a function of whether the trial judge is a former prosecutor or a former public defender. The latter claim is questionable as well because parties choose the enforcement institution. They can agree to a court, or choose arbitration and sometimes choose the actual arbitrator. A contrary view-- that the court's experience is helpful for interpretation-- is found in Posner, supra note 3 at 1603-06. For example, Judge Posner asserts, "But often, when the parties' intentions are not readily inferable from the written contract, the best, the most cost efficient, way to resolve their dispute is not to take testimony and conduct a trial: it is to use commercial or economic common sense to figure out how, in all likelihood, the parties would have provided for the contingency that has arisen had they foreseen it." Id. at 1605.
} 
contract required a greater quality level than the compliant quality level the seller supplied. Given symmetry - the court is as likely to err on the high side as the low side - the court's high and low side errors cancel out. Hence, the compliant seller receives her expectation with probability that exceeds one half. ${ }^{54}$

However, the seller may have an incentive not to comply: her expectation is price less cost, and the cost of a cheating performance is less than the cost of a compliant performance. But now the probabilities disadvantage the seller. She will have to pay damages to the buyer with a probability that is the sum of the probability that the court renders a correct interpretation and the probability that the court makes a high side error (it finds that the contract requires a performance that exceeds the true contract quality). The seller profits from cheating only if the court finds that the contract required the noncompliant performance that the seller actually tendered. This probability is small, however. Hence, the seller will not cheat unless the gain to cheating is very large (cheating can be done at low cost) or the gain to compliance is very small (a compliant performance generates little surplus for the parties to share). In the common case, cheating will not pay. ${ }^{55}$

\footnotetext{
${ }^{54}$ In this and the following note, we add a formal version of the argument we advance in text. Readers for whom the text is sufficient can skip these notes. Denote a compliant performance as $i^{*}$. The probability of a compliant performance, on our assumptions, is $p\left(i^{*}\right) \varepsilon[1 / 2,1]$. The seller's gain from complying and being found to comply is her expectation. The seller also receives her expectation if the court errs on the low side. The damages the seller pays if she is found not to comply are the buyer's expectation. If the parties have equal bargaining power, which is a standard assumption, the parties' expectations are equal: they split the expected surplus fifty/fifty. Denote the seller's expectation, which thus equals the buyer's damages, as e*. Then the seller's expected gain from complying is $\pi_{C}=e^{*}\left[p\left(i^{*}\right)+\frac{1-p\left(i^{*}\right)}{2}\right]-e^{*}\left[\frac{1-p\left(i^{*}\right)}{2}\right]=e^{*}\left(p\left(i^{*}\right)\right)$

${ }^{55}$ Denote the seller's gain from cheating as $\mathrm{G}=\mathrm{k}-\mathrm{q}$ where $\mathrm{k}$ is the contract price and $\mathrm{q}$ is the cost of a noncompliant performance. Then $\mathrm{q}<\mathrm{c}$, where $\mathrm{c}$ is the cost of the performance that complies with the
} 
To make this argument more vivid, consider a numerical example. Suppose the buyer values a conforming structure at $v\left(\mathrm{~S}^{*}\right)=120$ and this structure costs 80 to build. The structure is worth more to the buyer than to anyone else. The contractual surplus is 40 (value less cost). Thus, making the standard equal bargaining power assumption, the price is 100 (the 80 cost plus one half of 40) ${ }^{56}$ The court in this example is just barely more accurate than not. The probability that it will correctly construe the contract to require the seller to deliver a structure of quality $S^{*}$ is .55. With probability .225 , the court will interpret the contract to require the seller to deliver the lesser quality $\mathrm{S}^{-}$; and with probability .225 , the court will require the greater quality $\mathrm{S}^{+}$. In this illustration, the seller tenders a structure whose quality the court can observe. The interpretive issue is whether the contract required the seller to deliver that quality or some other quality. If the structure is found not to conform to the contract, the seller expects to sell it on the market at cost. $^{57}$

Assume initially that the seller produces the conforming structure $\mathrm{S}^{*}$. With probability .225 , the court finds that the seller over-complied - only $\mathrm{S}^{-}$was required - but she cannot get more than the price. Hence, she earns price less cost, which is 20 . With probability .55 , the court

contract. The seller's expected gain from cheating is

$$
\pi_{B}=G\left(\frac{1-p\left(i^{*}\right)}{2}\right)-e^{*}\left[p\left(i^{*}\right)+\frac{1-p\left(i^{*}\right)}{2}\right] .
$$

The seller complies if $\pi_{C}>\pi_{B}$. To get a sense of how likely compliance is, assume that the court is barely accurate: $p\left(i^{*}\right)=.55$. Then, saving the reader a lot of algebra, if cheating is costless $(q=0)$, the seller nevertheless complies if $\mathrm{c}<.83 \mathrm{k}$. The seller's profit is price less cost. Hence, when cheating is costless, and the court is barely accurate, the seller nevertheless complies unless her profit from compliance would be relatively small ( $17 \%$ or less of the price in this example). The cost even of a noncompliant performance probably exceeds zero by a substantial amount as well. Hence, cheating is unlikely.

${ }^{56}$ We omit for convenience a term that reflects the seller's expected damage liability. As said above, when the seller complies, her expected damage liability is zero.

${ }^{57}$ Recall that the buyer values the particular structure the contract required more than any other buyer. 
correctly finds that the seller complied, and again she gets the price and earns 20 . With probability .225 , the court erroneously finds that the seller breached: she should have delivered $\mathrm{S}^{+}$. In this case, the seller is liable for expectation damages of $\mathrm{v}\left(\mathrm{S}^{*}\right)$ - price $=120-100=20$. The seller's expected payoff from complying with the contract thus is $.225(20)+.55(20)+.225(-20)=11$.

Now assume the seller cheats by actually producing the $S^{-}$structure at the lower cost of 40 , one half of the compliance cost. With probability .225 , the court finds that the contract required the seller to produce only an $\mathrm{S}^{-}$structure so the buyer must pay the full price for a degraded performance. The seller then earns 60 -- the 100 price less her 40 cost. With probability .55, the court finds that contract required the seller to deliver an $\mathrm{S}^{*}$ structure so the seller is in breach. The seller will then sell the structure at her cost of 40 and pay damages of 20 to the buyer. With probability .225 , the court erroneously finds that the contract required the seller to produce the $\mathrm{S}^{+}$ structure so she again is in breach and must pay damages of 20. The seller's expected return if she cheats thus is $.225(60)+55(-20)+.225(-20)=-2$. The seller thus will not cheat when she expects to face a barely accurate court.

We summarize the intuition that supports the example: A seller who cheats earns a positive return when the court construes the contract to require only the performance that she tendered. However, the court is more likely to find that the contract required a conforming performance. Moreover, even an accurate court may find that the contract required a greater performance than the contract actually requires. The cheating seller benefits from errors on the low side but loses both from correct interpretations and from errors on the high side. Therefore, the seller commonly realizes a higher expected payoff when she attempts to comply with the contract than when she cheats. In Part IIID below, we review the evidence that shows parties prefer textualist interpretations. The analysis here shows that these interpretations are good enough to support efficient contracting. ${ }^{58}$

\footnotetext{
${ }^{58}$ The argument in text made two important assumptions. First, it assumed a symmetric distribution of
} 


\section{Accuracy, Context and Party Preferences}

Almost all of our critics erroneously claim that we urge courts to interpret contracts on narrow evidentiary bases. ${ }^{59}$ On the contrary, we urge courts to follow party preferences regarding the interpretive rules. It is the parties, we claim, who commonly prefer textualist interpretations.

Critics also argue that parties prefer contextual interpretations because these are more accurate. As we point out above, this response does not engage our claim because it assumes that judicial accuracy comes at zero cost. We engage the accuracy issue more deeply here. The ground of the objection is summarized in the claim that words are meaningless unless they are read in context. We are taken to prefer courts to interpret contracts without reference to context.

To the contrary, we agree that context is crucial to interpretation, though not exactly for the reasons our critics' espouse. Rather, context is necessary for finding whether a performance

possible interpretations, but parties sometimes face skewed distributions. The common practice in these cases is for parties to contract into symmetric distributions. See Contract Theory at 581-83. Second, the text assumed that the probability distribution is invariant to the nature of the seller's performance. This assumption may seem unrealistic because the court sees the performance, and may update its interpretation to reflect that performance. The motivation for assuming that the probabilities are unchanged is as follows. Let the court see the contract and the pleadings, and use its experience to infer that the parties at bar are among the set of contracting types that intend to trade $\mathrm{S}^{*}$ structures. The parties write the contract, recall, so that the probability the court will $r$ each this conclusion exceeds one half. Now assume that the seller produces $\mathrm{S}^{*}$. When the court sees $\mathrm{S}^{*}$, its view is confirmed: the parties actually are among the types that intend to trade $\mathrm{S}^{*}$ structures. Hence, the seller has rendered a compliant performance by producing one. Assume instead that the seller produced the noncompliant structure $\mathrm{S}^{-}$. A sophisticated court would not update its prior to increase the probability that the parties are among the contracting types that intend to trade $S^{-}$structures, so that the seller complied by producing one of them. Parties would have a strong incentive to degrade performances were courts to increase their probability that degraded performances were intended from observing a degraded performance. Rather, a court rationally treats a degraded performance as having no informational content. Hence, we assume that the seller expects to face the same probability distribution of interpretations whether she complies or not. For further justification of this line of reasoning, see Schwartz and Watson, supra note -

$-$

${ }^{59}$ Professors Burton and Bayern make this mistake frequently. See, e.g., Burton, supra note 7 at 36 ; Bayern, supra note 6 at 104 ("E]conomic formalism posits that the law will function better, in view of the costs of adjudication, if courts narrowly limit the field of information or arguments that they permit themselves to consider when hearing cases."). 
conforms to the contract. Recall again the illustration regarding the construction of a structure of specified dimensions. Assume that the buyer is a chemical company that plans to use the structure to store dangerous chemicals. A structure that complies with Federal regulations regarding chemical storage would be conforming while a structure that resembles a gazebo would clearly be deficient. Hence, a court cannot interpret a contract that requires the seller to deliver "a structure" (even one whose dimensions are specified) without knowing the context: the buyer's business and his plan.

A minimum evidentiary basis ordinarily is sufficient to convey sufficient contextual information. For example, the pleadings and supporting briefs, evidence as to what the seller delivered, the contract, a recent 10K SEC filing by the buyer (if any) ${ }^{60}$ and the life experience of the judge, together are likely to permit a court correctly to decide that an agreement between a professional construction company and a chemical company is unlikely to be satisfied by the delivery of a gazebo.

${ }^{60}$ A $10 \mathrm{~K}$ contains an extensive description of the filer's business. 32 
This view is made more plausible when one remembers that the court sees what the parties want it to see. ${ }^{61}$ Recall the timing of the interpretation game described above in Part IIA. The state moves first by choosing the rules. The parties then move by creating the contract. ${ }^{62}$ At this stage, the parties know their context, so they can decide whether to include context evidence in the contract. The court next moves by resolving any interpretive dispute. The parties thus know, when they create the contract, what the court will later see. Suppose then that the court is expected to use a minimum evidentiary base. The actual width of that base is significantly endogenous. For example, the "whereas clause" in the contract to deliver a structure can describe the buyer's business and his contemplated use of the structure, and appendices to the contract can contain the specifications that the structure is to meet and any memoranda the parties want an interpreting court to use. ${ }^{63}$

An argument that parties prefer courts to use broad evidentiary bases thus loses force when it is recognized that parties have substantial control over the width of the base. To be sure, ex post one party may want the court to see particular bits of evidence that the other wants excluded. The issue, however, is whether, ex ante, the party wanted the opportunity to introduce such evidence. We argue that business firms commonly reject that opportunity because they expect to get satisfactory interpretations without it.

${ }^{61}$ This is trivially true in a default world: parties who want courts to see more than we suppose would contract out of our default and parties who want courts to see less than they now see would contract for our rule if the current rules were defaults.

${ }^{62}$ See infra text accompanying notes 26-27.

${ }^{63}$ Courts thus apply the plain meaning or "four corners" rules with considerable knowledge of the agreement's context. Our claim is that in the common case courts do not need the additional contextual insight that eßßdence bits such as industry custom or prior practice would yield in order to be right on average. 
There is a need for such interpretations because contracts seldom conclusively settle things. Professor Bayern apparently believes, to the contrary, that parties do settle everything that they consider. In his words, it is "wildly improbable" for parties to consider a subject to the point of writing down a solution, but not have the solution resolve the issue. ${ }^{64}$ This reasoning leads him to claim that we erroneously distinguish gap filling from interpretation. If the written words settle everything, any dispute must involve an issue that the writing does not treat. Hence, the interpretation function collapses into the gap filling function.

This claim is incorrect. To see why, consider again the contract to deliver a structure of specified dimensions. It may be that the chemical company actually wanted a gazebo to decorate the lawn in front of its office. Parties assist courts by communicating context information in their contracts. Thus, the whereas clause in the contractor/chemical company contract could recite either that the parties want a structure for decoration or that they want a structure for storage. To see the problem with Bayern's claim, imagine that each piece of information that describes a part of the full context is a 'bit.' The contract may require a number of bits to describe the subject of sale: the size of the structure is a bit, its weather resistant properties another, and so forth. The industry in which the parties' function would require additional bits to describe.

Writing context bits is costly. Each additional bit, however, increases the probability that the court will make the correct interpretation, and so each bit increases the parties' expected payoff under the contract. Now make two standard assumptions. First, the expected gain from including bits is concave; that is, the first few bits greatly increase the probability that the court will make the correct interpretation while the last few bits only slightly increase that probability. Second, contract writing costs are convex: the contract becomes more costly to write as it adds contextual bits, and contract writing costs increase at an increasing rate. On these assumptions, there commonly is an "internal solution" to the parties' contract writing problem: parties will include contextual bits until the marginal gain - the increased expected contractual payoff - from further

\footnotetext{
${ }^{64}$ Bayern, supra note 6 at $118,119 \& 130$.
} 
bits equals the marginal cost of writing them. In the usual case, the internal solution yields a contract that contains fewer than all the bits required to describe context perfectly. ${ }^{65}$ It actually is "wildly improbable" for the optimal solution to the typical parties' contract writing problem to require the parties to state every conceivably relevant thing. When things are left out, however, the contract may require interpretation. Therefore, the interpretation function is both significant and exists independently of the gap filling function. ${ }^{66}$

\section{The Evidence}

Our earlier analysis, and the review here, are theoretical. The sketchy evidence that exists is consistent with our account, however, and offers no support to our critics. To begin, parties explicitly attempt to alter common judicial interpretive practices. A common provision found in alliance agreements thus recites:

The Parties' legal obligations under this Alliance Agreement are to be determined from the precise and literal language of this Alliance Agreement and not from the imposition of state laws attempting to impose additional duties of good faith, fair dealing or fiduciary obligations that were not the express basis of the bargain at the time this Agreement was made.

The Parties are sophisticated business entities with legal counsel that have been retained to review the terms of this Alliance Agreement and the Parties represent that they have fully read this Alliance Agreement, and understand and accept its terms. ${ }^{67}$

In addition, parties often direct courts to ignore prior negotiations, oral understandings and course

${ }^{65}$ To formalize this point, let $\mathrm{N}$ be the number of bits required to describe the parties' context perfectly, so that the court could not mistake what the parties agreed to deliver. Hence, the number of bits the parties use in a contract can be all of $\mathrm{N}$ or a subset of $\mathrm{N}$. We can denote the optimal -- i.e., the cost justified -- number of bits for a particular contract as $n\left(k^{*}\right) \varepsilon[1, \ldots ., N]$. Based on the two assumptions in text, an optimal contract contains less than all $\mathrm{N}$ bits: $\mathrm{n}\left(\mathrm{k}^{*}\right)<\mathrm{N}$. Given concavity in the return function, the argument in text also goes through if contract writing costs are non-decreasing in the number of bits. An illuminating way to put this conclusion is that there commonly exists "contextual information asymmetry" between parties and courts.

${ }^{66}$ Contract writing problems of this type are formally analyzed in Schwartz \& Watson, supra note 40. The challenge parties face in writing express contract terms that minimize later interpretative disputes over meaning is discussed in Goetz \& Scott, supra note 35 at 281-286.

${ }^{67}$ Alliance Agreement - E. I. du Pont de Nemours and Co. and EarthShell Corp.,, available at: onecle.com, http://www.onecle.com, and the Contracting and Organizations Research Institute, http://cori.missour.edu. --- 
of conduct and instead to limit their consideration to the "appropriate documents in final form ... executed and delivered by each of the In the same vein, parties routinely write merger or integration clauses that attempt, though sometimes unsuccessfully, to restrict the evidence courts admit when interpreting their contracts. ${ }^{69}$ The data go beyond anecdotal evidence from individual contracts. Lisa Bernstein's work shows that parties who are members of trade associations - and thus who rely on both informal or relational enforcement as well as third party

${ }^{68}$ SCOTT \& KRAUS, supra note 29 at 228 , note 13 . See e.g., the following typical exclusionary clause:

No legally binding obligations on the parties will be created, implied, or inferred until appropriate documents in final form are executed and delivered by each of the parties regarding the subject matter of this [agreement] and containing all other essential terms of an agreed upon transaction. Without limiting the generality of the foregoing, it is the parties intent that, until that event, no agreement binding on the parties shall exist and there shall be no obligations whatsoever based on such things as parol evidence, extended negotiations, "handshakes," oral understandings, or course of Id. conduct (including reliance and changes of position).... [emphasis added].

${ }^{68}$ SCOTT \& KRAUS, supra note 29 at 228 , note 13 . See e.g., the following typical exclusionary clause:

No legally binding obligations on the parties will be created, implied, or inferred until appropriate documents in final form are executed and delivered by each of the parties regarding the subject matter of this [agreement] and containing all other essential terms of an agreed upon transaction. Without limiting the generality of the foregoing, it is the parties intent that, until that event, no agreement binding on the parties shall exist and there shall be no obligations whatsoever based on such things as parol evidence, extended negotiations, "handshakes," oral understandings, or course of Id. conduct (including reliance and changes of position).... [emphasis added].

${ }^{69}$ Merger clauses are ubiquitous in contracts between firms. For a typical example, see the following: This Contract constitutes the entire agreement of the parties hereto and supersedes all prior and contemporaneous agreements, representations, and understandings of the parties. No waiver of the provisions of this Contract shall be deemed or shall constitute a waiver of any other provisions, nor shall any waiver constitute a continuing waiver. This Contract may not be supplemented, altered, modified or amended or otherwise changed except by an instrument in writing signed by the parties hereto. The course of dealing or course of performance between the parties hereto shall not commit either party to duties or obligations which are not expressly stated by this Contract.

Fruit Purchase Contract between Cargill Juice North America, Inc., and South Ford Meade Land Mgt. Available at http://ronald.cori.missouri.edu/cori_search/Contract 
enforcement — preserve formal interpretive rules and reject contextualized standards. ${ }^{70}$

Our analysis also generates an empirical prediction. As noted above, New York courts are textualist when using the common law while California courts are contextualist. Thus, we predict that parties will contract into New York law when they can, but will not contract into California law. Recent work by Ted Eisenberg and Geoff Miller studying choice of law and choice of forum clauses in a data set of 2,865 contracts is consistent with this prediction. ${ }^{71}$ Their study shows that parties chose New York law in $46 \%$ of the contracts and New York as the forum state in $41 \%$ of the contracts. ${ }^{72}$ California was chosen for its contract law in less than $8 \%$ of the contracts, though its commercial activity, as measured by the place of business of the contracting parties, was second only to New York.

Geoff Miller uses the differences in contract law between New York and California to explain this large difference in party preferences. ${ }^{73}$ His analysis confirms the conventional wisdom: New York strictly enforces bargains, retains a hard parol evidence and a plain meaning rule and frequently declines to consider context evidence in resolving interpretive disputes. California, in contrast, has a contextualist interpretive regime and is predisposed to consider all material context evidence that litigating parties seek to introduce. Miller concludes that "the

\footnotetext{
${ }^{70}$ See Lisa Bernstein, Private Commercial Law in the Cotton Industry: Creating Cooperation Through Rules, Norms, and Institutions, 99 Mich. L. Rev. 1724, 1745-54, 1762-87 (2001) (discussing existence, importance, and supporting institutional conditions of formalist interpretation together with reputation-based non-legal sanctions in cotton industry); Lisa Bernstein, Merchant Law in a Merchant Court: Rethinking the Code's Search for Immanent Business Norms, 144 U. Pa. L. Rev. 1765, 1771-77, 1787-95, 1815-20 (1996) (concluding that formalist contract enforcement by private system of merchant courts established by National Grain and Feed Association results from recognition of, and to support, role of extralegal, reputational sanctions).

${ }^{71}$ Theodore Eisenberg \& Geoffrey P. Miller, The Flight to New York: An Empirical Study of Choice of Law and Choice of Forum Clauses in Publicly-Held Companies'Contracts (mimeo 2007).

${ }^{72}$ Id. at 18-19. Delaware was a distant second to New York, with about $15 \%$ of the parties choosing its law. No other state accounted for even $10 \%$ of the choices of law. Id.

${ }^{73}$ Geoffrey P. Miller, Bargaining on the Red-Eye: New Light on Contract Theory (N.Y.U. Ctr. For Law \& Econ., Working Paper No. 131, 2008 (mimeo 2008), available at http://sr.nellco.org/nyu/lewp/papers/131.
} 
revealed preferences of sophisticated parties support arguments by Schwartz, Scott and others that formalistic rules offer superior value for the interpretation and enforcement of commercial 4.

We claim that interpretive rules should be defaults in a goal neutral interpretive regime. This claim implies that the rules should reflect the preferences of the parties who must live under the rules. Their preferences, we argue, most commonly direct courts to interpret contracts on narrow evidentiary bases. This argument is supported by theory and is consistent with the evidence.

\section{Interpretation as a Litigation Problem: How Textualist and Contextualist REGIMES WORK ${ }^{75}$}

The interpretation debate has been theoretical, but interpretation issues arise in litigation contexts. These contexts require courts to choose between two arguments about what the contract requires. We sketch out the doctrinal framework that controls how courts make this choice. Our object is to make salient an underappreciated virtue of formalism: it permits parties to design contracts so as optimally to trade off contract writing costs and expected litigation costs. ${ }^{76}$

\footnotetext{
${ }^{74} \mathrm{Id}$. at 1 et seq.

${ }^{74} \mathrm{Id}$. at 1 et seq.

${ }^{75}$ The following description of the sequence in which contract litigation disputes proceed in litigation was developed in conversations with a number of commercial litigators as well as from the experiences that both of the authors have had serving as expert witnesses in contract litigations.
}

${ }^{76}$ Albert Choi and George Triantis argue that parties sometimes want to increase their cost of proving outcome variables such as an agent's effort after the contract is concluded. The parties realize this goal by conditioning contractual payoffs on these costly to verify variables. See Albert Choi and George Triantis, Completing Contracts in the Shadow of Costly Verification, 37 J. Legal Studies 503 (2008). The contracts that do this have the virtues of increasing the expected value of the sanction for breach (the breacher bears the high litigation cost) and deterring litigation that has a low probability of success. This interesting theory is not relevant to the case for cost reduction that we make. Choi and Triantis focus on outcome variables, but interpretation issues require courts to recover "context variables": information that details the parties' circumstances when the parties contracted. Thus, in an illustration above, the outcome variable was the quality of the structure the seller delivered; the context variables were the business the parties were in and the 
Situating the interpretation debate in its institutional environment thus further clarifies the formalist case.

Interpretive disputes require courts to identify the contract's terms and then to interpret those terms. The answers to identification and interpretation questions do not turn on the parties' subjective understandings but rather on the objective manifestations of their intent at the time of contract. ${ }^{77}$ We next show how the doctrine, ideally applied and in connection with the contract, helps parties to control the evidentiary base on which courts will interpret their agreements.

\section{A. Recovering the Contract Terms: The Parol Evidence Issue}

The parol evidence rule functions to permit parties to control the admissibility of certain kinds of evidence. The rule holds that when parties fully integrate a final written agreement, they cannot later prove understandings that the integrated writing did not contain. Parties may want to exclude evidence of possible understandings reached during the contracting process for three reasons: (a) tentative agreements may later be abandoned; (b) agents may misrepresent their principal's commitments during the course of negotiations while the final agreement likely will set things straight; or (c) parties may prefer to exclude a portion of their agreement from legal enforcement.

purpose for which they dealt. Choi and Triantis do not argue that parties prefer to increase their cost of establishing context variables, and we believe that parties prefer not to do so. The better informed the court is about context, the more likely the court is to recover the parties' intentions. Hence, parties prefer to reduce the cost of communicating context evidence. It is consistent with the Choi and Triantis theory that parties want to reduce the cost of showing what the agent was supposed to do while also wanting to increase the cost of proving what the agent actually did. This is because the cost of proving an outcome variable cannot be relevantly increased unless the court knows what the contract requires the party to prove.

${ }^{77}$ Professor Bayern apparently assumes that a court that accepts the objective theory of contract is necessarily committed to a formalist theory of interpretation. See Bayern, supra note 6 at 122, n. 53 (suggesting that if the question of intent is determined objectively and prospectively "there is little else for critics of the argument to do but reject the [objective] axiom."). His assumption is incorrect. Courts in a contextual regime admit more evidence than courts in a formal regime, but the evidence in both regimes is used to answer the same question: what could the promisee reasonably take the promisor to have promised? 
The common law consistently defers to these reasons, treating the decision to integrate an agreement as in the parties' discretion. ${ }^{78}$

American courts, however, divide over the appropriate test for determining whether or not parties intended to integrate part or all of their agreement into an exclusive, legally enforceable writing. ${ }^{79}$ Formalist courts, such as common law courts in New York, use a hard parol evidence rule. ${ }^{80}$ Derived from the traditional rule at common law, a hard parol evidence rule gives presumptively conclusive effect to merger clauses, ${ }^{81}$ and, in the absence of such a clause, determines whether the written agreement is fully integrated by applying the four corners presumption. ${ }^{82}$ This presumption holds that the contract is fully integrated if it appears final and

\footnotetext{
${ }^{78}$ Kraus \& Scott, supra note 29 at 22.

${ }^{79}$ See, e.g., Eric Posner, The Parol Evidence Rule, the Plain Meaning Rule, and the Principles of Contractual Interpretation, 146 U. Pa. L. Rev. 533, 534 (1998) (distinguishing two polar positions: AhardPER" where Athe court generally excludes extrinsic evidence and relies entirely on the writing, and >soft$\mathrm{PER},=$ where the court gives weight both to the writing and to the extrinsic evidence. $a$ ). See also Ralph Mooney, The New Conceptualism in Contract Law, 74 OR. L. REV. 1131, 1132-5 (1995) (identifying split between hard and soft interpretive regimes); Robert Hillman, The New Conservatism in Contract Law and the Process of Legal Change, 40 B.C. L. REV. 879, 889-902 (1999) (identifying same split). For discussion, see SCOTT \& KRAUS, supra note 30 at 578-618.
}

${ }^{80}$ See, e.g., Mitchill v. Lath, 160 N.E. 646, 647-8 (N.Y. 1928) (upholding "four corners presumption" and excluding evidence of collateral agreement to land sale contract); Intershoe v. Bankers Trust Co., 571 N.E. $2 d$ 641,644 (N.Y. 1991) (prior agreement excluded where writing appears in view of thoroughness and specificity to embody a final agreement); Morgan Stanley High Yield Securities, Inc. v. Seven Circle Gaming Corp., 269 F. Supp. 2d 206 (S.D.N.Y. 2003) (same).

${ }^{81}$ Merger clauses are given virtually conclusive effect in New York. See Tempo Shain Corp. v. Bertek, Inc., 120 F.3d 16, 21 (2d Cir. 1997) ("[O]rdinarily, a merger clause provision indicates that the subject agreement is completely integrated, and parol evidence is precluded from altering or interpreting the agreement."); Jarecki v. Shung Moo Louie, 745 N.E.2d 1006, 1009 (N.Y. 2001) ("[T] he purpose of a merger clause is to require the full application of the parol evidence rule in order to bar the introduction of extrinsic evidence. ... The merger clause accomplishes this purpose by evincing the parties' intent that the agreement 'is to be considered a completely integrated writing.'); Norman Bobrow \& Co., Inc. v. Loft Realty Co., 577 N.Y.S.2d 36, 36 (App. Div. 1991) ("[p]arol evidence is not admissible to vary the terms of a written contract containing a merger clause.").

${ }^{82}$ Courts have long recognized that a writing can be found to be a total integration even in the absence of a merger clause. See e.g., Morgan Stanley High Yield Securities, Inc. v. Seven Circle Gaming Corp., 269 F. 
complete on its face. A hard parol evidence rule thus maximizes party discretion over the content of the legally enforceable contract: it functions as a procedural default rule that shrinks the evidentiary base on which the court finds the terms of the contract, but the rule permits parties to expand that base as they see fit. When parties fully integrate the agreement and use a merger clause, an interpretation dispute over contract terms may be resolved on summary judgment.

Anti-formalist jurisdictions, such as California, favor a soft parol evidence rule. ${ }^{83}$ The test for integration in these states admits extrinsic evidence of meaning, although the writing has an unambiguous merger clause, or would appear final and complete on its face under the four corners presumption. ${ }^{84}$ Anti-formalist courts believe that a merger clause raises a rebuttable presumption of integration that may be overridden by extrinsic evidence that the parties lacked the intent to integrate. 85 When a merger clause is absent, soft rule courts reject the four corners presumption in

Supp. 2d 206, 214 (S.D.N.Y. 2003) ("Under New York law a contract which appears complete on its face is an integrated agreement as a matter of law.") Mitchill v. Lath, 160 N.E. 646 (N.Y. 1928 (using "natural omission test" to exclude evidence of separate oral agreement to add to terms of deed that appeared complete on its face despite absence of merger clause). See also SCOTT \& KRAUS, supra note 30 at 541-43 (discussing the tests for total integration in the absence of a merger clause).

${ }^{83}$ Masterson v. Sine, 436 P.2d. 561, 563 (1968) (admitting parol evidence to vary terms of deed on ground that "evidence of oral collateral agreements should be excluded only when the fact finder is likely to be misled"); Pacific Gas \& Elec. Co. v. G.W. Thomas Drayage \& Rigging Co., 442 P.2d 641, 644 (1968) (" $[R]$ ational interpretation requires at least a preliminary consideration of all credible evidence offered to proved the intention of the parties."). See also Susan Martin-Davidson, Yes, Judge Kozinski, There Is a Parol Evidence Rule in CaliforniaBThe Lessons of a Pyrrhic Victory, 25 Sw. U. L. REV. 1 (1995) (examining California cases raising the issue of admissibility of extrinsic evidence and concluding that parol evidence jurisprudence in California represented one of the most confused and incoherent areas of law in the state). See note 2 supra.

${ }^{84}$ Miller, Bargaining on the Red-Eye, supra note 71 at $41-43$.

85 Int'1 Milling co. v. Hachmeister, Inc., 110 A. 2d 186 (1955) (extrinsic evidence of negotiations and antecedent agreements admissible to show buyer had not assented to the contract as a complete integration of the contract despite the presence of an express merger clause); See also, 3 Corbin Contracts, §578 (199-) ("The fact that a written document contains one of these express provisions does not prove that the document itself was ever assented to or ever became operative as a contract. Neither does it exclude evidence that the document was not in fact assented to and therefore never became operative"); Restatement (Second) of Contracts $\S 216$, comment e (same). 
favor of admitting any extrinsic evidence that may aid in determining the parties intent to integrate their writing. ${ }^{85}$ A court that uses a soft parol evidence rule is likely to deny a motion for summary judgment, thus increasing the expected litigation costs of both parties. Moreover, a soft parol evidence rule functions, in effect if not formally, as an open gate: any extrinsic evidence that a party sees as advantageous ex post will likely be considered. Thus, contrary to the stated purposes of the rule, the soft version withdraws from parties the ability to determine the evidentiary base that the court will later see.

\section{B. Resolving Disputes over the Meaning of Contract Terms}

The parol evidence question is logically prior to the question of what legal "meaning" should be attributed to the contract terms. Contrary to standard anti-formalist claims, courts do not convert meaning inquiries into ventures in the philosophy of language ${ }^{86}$ This is not to say that context is irrelevant - any inquiry into the intended meaning of words is necessarily contextual but rather to make clear that the parties can importantly determine the context within which any meaning inquiry is conducted. When parties write a fully integrated contract, they are attempting to embed much of the context for determining meaning within the written agreement itself. A variety of contract clauses perform this function. These include (a) "whereas" or "purpose" clauses that describe the parties' business plan and the transaction; ${ }^{87}$ (b) definition clauses that

\footnotetext{
${ }^{85}$ In sales cases that fall under Article 2 of the UCC, courts are instructed as well to follow a soft parol evidence rule and to reject the plain meaning rule. See UCC § 2-202, Comment 1 ("This section definitely rejects: (a) any assumption that because a writing has been worked out which is final on some matters, it is to be taken as including all the matters agreed upon; (b) the premise that he language used has the meaning attributable to such language in rules of construction existing in the law rather than the meaning which arises out of the commercial context in which it was used...).

${ }^{86} \mathrm{Cf}$, Burton, supra note 7 at 220 -223; Lipshaw, supra note 6 at 112-116.

${ }^{87}$ See e.g., the following "purpose" clause from the Fountain Manufacturing Agreement between Apple Computer, Inc. and SCI Systems, Inc., available at http://contracts.onecle.com/apple/scis.mfg. 1996.05.31.shtml http://cori.missour.edu.

PURPOSE
} 
ascribe particular meanings to words and terms that may vary from their plain meaning; ${ }^{88}$ and (c) appendices that provide more precise specifications governing performance as well as any memoranda the parties want an interpreting court to use. ${ }^{89}$

Contests over the meaning of contract terms thus follow a predictable pattern: one party claims that the words in a disputed term should be given their standard dictionary meaning, as read in light of the contract as a whole, the pleadings and so forth. The counterparty argues either that the contract term in question is ambiguous and extrinsic evidence will resolve the ambiguity, or that extrinsic evidence will show that the parties intended the words to be given a specialized or idiosyncratic meaning that varies from the meaning in the standard language. As with the division

Apple and SCI entered into a Stock Purchase Agreement on April 4, 1996 (the "Stock Purchase Agreement") pursuant to which SCI will purchase Apple's manufacturing facility located at 702 Bandley Drive, Fountain, Colorado ("Fountain") and certain related assets.

The parties desire that Apple engage SCI to assemble, test and package certain Products, Service Units and Spare Parts, as defined below, on a turnkey basis at Fountain on the terms and conditions of this Agreement.

This Agreement defines the general terms and conditions governing all transactions between them for Products, Service Units and Spare Parts manufactured at Fountain. Individual "Product Plans" attached as Addenda to this Agreement, and incorporated herein by reference, define the specific terms and conditions for each Product, Service Unit and/or Spare Part. The initial Product Plans are attached to Exhibit A and numbered A-1 through A-11. Additional Products and Product Plans may be added to this Agreement by addenda to Exhibit A signed by both parties. Such addenda will be numbered sequentially, A-12, A-13 and so on.

In consideration of the above and the mutual promises contained herein, Apple and SCI agree as follows:

${ }^{88}$ See ,e.g., Data Management Outsourcing Agreement Between Allstate Insurance Company and Acxiom Corporation, Art. 2. DEFINITIONS (defining 34 technical or non-standard meanings including specialized meanings of "Agreement," "Confidential Information," Data Integrity," "Current Projects", "Affiliate," "End User," "Material Default," "Party," "Person," "Problem," "Term,"' "Work Order," and "Work Product."), available at

${ }^{89}$ See e.g., Apple/SCI Manufacturing Agreement, supra note 85. 
over hard and soft parol evidence rules, courts have divided on the question whether express contract terms should be given a "contextual" or a "plain meaning" interpretation. ${ }^{90}$ Under the latter practice, when words or phrases appear to be unambiguous, extrinsic evidence of a possible contrary meaning is inadmissible.

The plain meaning rule operates in tandem with a hard parol evidence rule to reduce expected adjudication costs. If the contract is fully integrated, and if contractual terms are facially clear, then the dispute can be resolved at summary judgment. Parties may realize this cost advantage whether or not contextual inquiries into meaning exacerbate the risk of strategic behavior in litigation. ${ }^{91}$ Parties who want the court to see additional evidence, but avoid trials, can (and must) embed the evidence in the contract itself. In this way, the plain meaning rule functions as a useful aid to contract design, which offers parties the opportunity either to expand or to contract the context on which meaning questions are decided. A contextual meaning rule, on the other hand, limits parties' freedom to narrow the interpretive context even when doing so would maximize the expected value of the contract. ${ }^{92}$

\footnotetext{
${ }^{90}$ See SCOTT \& KRAUS, supra note 30 at 543-5, 578-602 (discussing differences between plain meaning and "contextual" modes of interpretation); Schwartz \& Scott, supra note 4, at 584-94 (arguing that most parties would prefer plain meaning interpretation because it would (a) reduce contracting costs; (b) minimize the opportunities for strategic behavior; (c) reduce the risk of judicial error; and (d) expand the set of efficient contracts parties could write).

${ }^{91}$ See infra text accompanying note 51-55.

92 The discussion in text assumes that there is a "correct answer" to an interpretive dispute over meaning. But what if there is a genuine ambiguity in the written agreement? In such a case, the divide between formalist and anti-formalist positions essentially disappears: a court will consider extrinsic evidence to resolve the ambiguity. If the ambiguity cannot be resolved by additional evidence, the contract may be found too indefinite to enforce. See e.g., Raffles v. Wickelhaus, 2 H \& C 906, 159 Eng. Rep. 375 (1864) (holding that "there was no consensus and therefore no binding contract" over sale of cotton on one of two ships named "Peerless" sailing from Bombay to Liverpool within three months of each other). Alternatively, depending on the burden of proof, there may be a verdict favoring one of the dueling interpretations offered by the parties. See e.g., Frigaliment Importing v. B.N.S. International Sales, 190 F. Supp. 116 (S.D.N.Y.1960). (finding that the meaning of "chicken" was vague and holding for seller on the grounds that buyer, as plaintiff, had not carried its burden of proving which of the two plausible meanings the parties intended.) For discussion, see Robert E. Scott \& George G. Triantis, Anticipating Litigation in Contract Design, 115 Yale L. J. 814, 859-
} 
The preceding discussion illustrates that it is important for parties to control by contract the rules that determine the evidentiary base for resolving interpretive disputes. Sophisticated commercial parties incur costs to cast obligations expressly in written and unconditional forms to permit a party to stand on its rights under the written contract, to improve party incentives to invest in the deal, and to reduce litigation costs. Parties know better than courts how best to trade off these front-end and back-end contracting costs. Contextualist courts and commentators prefer to withdraw from parties the ability to use these instruments for contract design. The contextualists, however, cannot justify rules that so significantly restrict contractual freedom in the name of contractual freedom.

\section{CONCLUSION}

Interpretative rules follow from interpretive theories. The regnant theory is goal neutrality: the interpreter's task is to recover the parties' objectively manifested intentions, whatever those intentions may have been. We argued in Contract Theory, and argue again here, that the current interpretive rules cannot be derived from the current interpretive theory. The rules of the Restatement, the UCC and many jurisdictions are mandatory and require courts to use broad evidentiary bases when interpreting merchant to merchant contracts. Goal neutrality, in our view, best supports the conclusion that the interpretive rules which govern these contracts should be majoritarian defaults. This view raises the question: what are the majoritarian preferences? We have attempted to show that business parties commonly prefer courts to make interpretations on a narrow evidentiary base that includes the contract, the pleadings, evidence that does not involve the interpretation dispute and the life experience of the court. Extrinsic evidence is outside this base.

$60(2006)$. 
Our views have generated both interest as well as criticism, but much of the criticism does not engage our arguments. The central objection to our theory of interpretation is that contextual interpretation - the use of extrinsic evidence - yields more accurate results than acontextual interpretation. More evidence, that is, is better than less. Critics have not focused on the claim that goal neutrality implies default interpretive rules. If that argument is conceded, however, the critics' view reduces to a non-sequitur. The issue is not which interpretive rules yield more accuracy. The issue, rather, is which interpretive defaults best reflect the parties' preferred tradeoffs among accuracy in interpretation, contract writing costs and contract enforcement costs. Our critics largely ignore costs, and so they raise no effective challenge to our view regarding what are good defaults.

We end by acknowledging that much is still to be learned about contract interpretation. We attempt to contribute to this quest by identifying the right questions. Should the interpretive theory be goal neutrality or some substantive theory? What interpretive rules follow from any theory an analyst can plausibly defend? If those rules are defaults, what are the best reconstructions of party intent regarding interpretation? Identifying the rules that may permit a court best to recover the parties' intentions is just a step toward answering the right questions.

November 12, 2009. 